\title{
ANALISIS NILAI TUKAR RUPIAH DAN IMPLIKASINYA PADA PEREKONOMIAN INDONESIA: PENDEKATAN ERROR CORRECTION MODEL (ECM)
}

\author{
Imamudin Yuliadi \\ Fakultas Ekonomi Universitas Muhammadiyah Yogyakarta \\ E-mail: imamudin2006@yahoo.co.id
}

\begin{abstract}
The changing of exchange rate is due to interaction between economic factors and non-economic factors. The aim of this research is to analyse some factors that affect exchange rate and their implications on Indonesian economy. Analytical method used in this research is explanatory method is to test hypothesis about simultaneous relationship among variables that research by developing the characteristics of verificative research by doing some testing at every step of research. We used secondary data taken from BI, BPS, World Bank and IFS. We used error correction model (ECM) to analysis between independent variable and dependent variable in both the short run and long run. The result of this research shows that ratio between domestic interest rate and international interest rate did not affect negative and significantly to exchange rate. Capital flow affected negative and significantly. Balance of payment affected negative and significantly. Money supply affected positive and significantly. According ECM method that used in this research shows that the methodology is good to analyse because the magnitude of ECT is accept.
\end{abstract}

Keywords: investment rate, efficiency, error correction model, error correction term

\section{PENDAHULUAN}

Persoalan yang sedang dihadapi perekonomian Indonesia sekarang cukup kompleks menyangkut berbagai dimensi ekonomi baik sistem maupun kelembagaannya. Krisis ekonomi yang melanda Indonesia diawali dengan timbulnya krisis nilai tukar Rupiah sebagai konsekuensi dari sistem keuangan yang semakin terintegrasi secara global. Membaiknya perekonomian Indonesia dan ditunjang dengan stabilitas politik yang mantap dan kecenderungan penurunan suku bunga di negara maju mendorong masuknya aliran dana ke Indonesia dalam jumlah cukup besar pada tahun 1990-an. Masuknya aliran modal ke dalam negeri disamping membawa berkah dapat mendorong laju investasi juga menimbulkan kekhawatiran kemungkinan terjadinya penarikan dana dalam jumlah besar dan dalam jangka waktu yang singkat dipicu oleh berbagai faktor domestik atau luar negeri (contagion effect) sehingga akan menggoyahkan fundamental ekonomi yang sudah terbina selama ini. Di samping itu yang menjadi pemicu utama krisis ekonomi di Indonesia adalah besarnya utang luar negeri swasta yang sebagian besar berjangka waktu pendek tapi diinvestasikan pada sektor ekonomi untuk jangka waktu panjang dan 
tingkat resikonya tinggi seperti sektor properti dan tidak dilindungi dari resiko pergerakan kurs (currency mismatching). Informasi yang berkaitan dengan interaksi ekonomi antara satu negara dengan negara lain terlihat dari data neraca pembayaran internasional. Tabel 1 memperlihatkan perkembangan neraca pembayaran Indonesia selama tahun 2003 dari triwulan I sampai triwulan IV.

Neraca pembayaran internasional merupakan suatu catatan sistematis yang menunjukkan nilai aktivitas ekonomi suatu negara terhadap negara atau pihak asing selama satu periode tertentu. Sampai dengan triwulan IV 2003 neraca pembayaran Indonesia menun- jukkan angka surplus sebesar 1.432 juta \$ US turun dibandingkan dengan waktu yang sama tahun 2002 sebesar 2.217 juta \$ US. Secara total nilai neraca pembayaran tahun 2003 mengalami surplus sebesar 3.654 juta \$ US turun dibandingkan tahun 2002 sebesar 5.029 juta \$ US.

Fluktuasi nilai tukar Rupiah terhadap dollar AS dalam beberapa tahun terakhir menunjukkan kecenderungan stabil, hal ini terutama dipengaruhi oleh besarnya surplus neraca pembayaran yang disebabkan oleh penurunan defisit transaksi modal dan pada sisi lain meningkatnya surplus transaksi berjalan. Penguatan nilai mata uang Rupiah didorong semakin tingginya capital inflows

Tabel 1. Neraca Pembayaran Indonesia (Juta US/\$)

\begin{tabular}{lrrrr}
\hline \multirow{2}{*}{ Uraian } & \multicolumn{3}{c}{ 2003 } \\
\cline { 2 - 5 } & \multicolumn{1}{c}{ Tr. I } & \multicolumn{1}{c}{ Tr. II } & Tr. III & Tr. IV \\
\hline I. Transaksi Berjalan (Current Account) & 1285 & 2325 & 2360 & 1453 \\
A. Neraca Perdagangan & 5504 & 6241 & 6588 & 5399 \\
a. Ekspor, f.o.b & 16075 & 15484 & 16298 & 15397 \\
$\quad$ i. Non Migas & 12001 & 12082 & 12347 & 11590 \\
$\quad$ ii. Migas & 4074 & 3402 & 3951 & 3807 \\
b. Impor, f.o.b & -10571 & -9243 & -9740 & -9998 \\
$\quad$ iii. Non-migas & -8648 & -7534 & -7573 & -7974 \\
$\quad$ iv. Migas & -1923 & -1709 & -2167 & -2024 \\
B. Neraca Jasa & -3135 & -2259 & -3406 & -2760 \\
1. Transportasi, bersih & -1169 & -767 & -973 & -983 \\
2. Perjalanan, bersih & -178 & 351 & 565 & 384 \\
3. Jasa-jasa lainnya & -1788 & -1843 & -2998 & -2160 \\
C. Pendapatan, bersih & -1249 & -2026 & -1190 & -1743 \\
D. Transfer berjalan, bersih & 164 & 369 & 398 & 558 \\
II. Transaksi Modal dan Finansial & -946 & -203 & -630 & 827 \\
A. Transaksi Modal & - & - & - & - \\
B. Transaksi Finansial & -946 & -203 & -630 & 827 \\
1. Investasi Langsung & -406 & 257 & -203 & -245 \\
2. Investasi Portfolio & -189 & 906 & 121 & 1414 \\
3. Investasi lainnya & -351 & -1366 & -548 & -341 \\
III. Jumlah (I+ II) & 339 & 2123 & 1730 & 2280 \\
IV. Selisih Perhitungan & 599 & -1189 & -1379 & -848 \\
V. Neraca Keseluruhan & 938 & 934 & 350 & 1432 \\
VI. Lalu Lintas Moneter & -938 & 934 & -351 & -1432 \\
\hline
\end{tabular}

Sumber: Bank Indonesia, Statistik Ekonomi dan Keuangan Indonesia 
menyusul semakin membaiknya fundamental makroekonomi Indonesia, menguatnya mata uang regional terhadap dollar AS, selisih yang cukup signifikan antara tingkat bunga domestik dan luar negeri serta respon positf terhadap lancarnya pelaksanaan pemilihan umum 2004.

Fluktuasi kurs Rupiah dipengaruhi baik oleh kebijakan moneter maupun kebijakan fiskal. Sejalan dengan pemberlakuan Undang-undang Nomor 23 tahun 1999 tentang Bank Sentral mengenai efektifitas kebijakan moneter pada sistem nilai tukar mengambang otoritas moneter telah mengubah sistem operasi kebijakan moneter dari sistem operasi berdasarkan intermediate targeting yang diterapkan selama penerapan sistem nilai tukar mengambang terkendali menjadi sistem operasi berdasarkan inflation targeting.

Penelitian ini akan menganalisis mengenai fluktuasi nilai tukar Rupiah dan implikasinya pada perekonomian Indonesia dengan memasukkan beberapa variabel makro ekonomi. Melalui metode analisis dengan pendekatan error correction model (ECM) dapat diketahui pengaruh perubahan variabel nilai tukar Rupiah terhadap variabel makroekonomi lainnya.

Berdasarkan uraian dalam latar belakang penelitian di atas, maka dapat dirumuskan masalah pokok penelitian sebagai berikut: (1). Bagaimanakah pengaruh fluktuasi nilai tukar Rupiah terhadap rasio tingkat bunga domestik terhadap tingkat bunga internasional (RDNLN), neraca pembayaran (BoP), aliran modal $(\mathrm{CF})$, indeks harga konsumen (CPI), jumlah uang beredar (M1), (2). Bagaimana pengaruh fluktuasi nilai tukar Rupiah terhadap rasio tingkat bunga domestik terhadap tingkat bunga interna- sional (RDNLN), neraca pembayaran (BoP), aliran modal $(\mathrm{CF})$, indeks harga konsumen (CPI), jumlah uang beredar (M1) dalam jangka pendek dan jangka panjang, (3) Bagaimana pengaruh krisis ekonomi terhadap fluktuasi nilai tukar Rupiah.

Penelitian ini dilakukan dengan tujuan untuk menganalisis pengaruh fluktuasi nilai tukar Rupiah dan implikasinya terhadap perekonomian Indonesia. Secara spesifik tujuan penelitian ini dapat dirumuskan sebagai berikut: (1). Untuk menganalisis pengaruh fluktuasi nilai tukar Rupiah terhadap rasio tingkat bunga domestik terhadap tingkat bunga internasional (RDNLN), neraca pembayaran (BoP), aliran modal (CF), indeks harga konsumen (CPI), jumlah uang beredar (M1), (2). Untuk menganalisis pengaru fluktuasi nilai tukar Rupiah terhadap rasio tingkat bunga domestik terhadap tingkat bunga internasional (RDNLN), neraca pembayaran (BoP), aliran modal (CF), indeks harga konsumen (CPI), jumlah uang beredar (M1) dalam jangka pendek maupun jangka panjang, (3) Untuk menganalisis pengaruh krisis ekonomi terhadap fluktuasi nilai tukar Rupiah.

\section{TINJAUAN PUSTAKA}

Analisis mengenai perubahan pada pasar modal terhadap penentuan keseimbangan nilai tukar pada perekonomian terbuka telah banyak dikaji oleh beberapa ahli. Pada perekonomian di mana jumlah uang beredar ditentukan oleh pemerintah, maka permintaan uang dirumuskan dalam suatu fungsi likuiditas preferensi sebagai berikut: ${ }^{1}$

\footnotetext{
1 Pentti JK Kouri, 1975, Monetary Policy, The Balance of Payments and The Exchange Rate dalam David Bigman and Teizo Taya, 1984, Floating Exchange
} 
$\frac{\mathrm{M}^{\mathrm{d}}}{\mathrm{P}}=\mathrm{L}(\mathrm{r}, \mathrm{y})=\frac{\mathrm{M}^{\mathrm{s}}}{\mathrm{P}}$,

dimana:

$M^{d}=$ Permintaan uang

$M^{s}=$ Jumlah uang beredar

$P=$ Deflator harga domestik

$r=$ Tingkat bunga nominal domestik

$y=$ Pendapatan riil domestik

Permintaan mata uang domestik dalam bentuk obligasi merupakan fungsi tingkat bunga, tingkat depresiasi mata uang domestik yang diharapkan, pendapatan riil dan nilai pasar kekayaan secara riil yang dapat dirumuskan sebagai berikut: $^{2}$

$$
\begin{aligned}
\frac{B^{d}}{P}= & B\left(r, r^{*}+\pi_{e}, y, \frac{A}{P}\right)= \\
& D\left(r, r *+\pi_{e}\right) \frac{A}{P}-L(r, y)=\frac{B^{s}}{P}
\end{aligned}
$$

dimana:

$\mathrm{B}^{\mathrm{d}}=$ Permintaan mata uang domestik dalam bentuk obligasi

$\mathrm{B}^{\mathrm{s}}=$ Penawaran mata uang domestik dalam bentuk obligasi

$\mathrm{D}(\mathrm{)}=$ Jumlah total permintaan kekayaan domestik

A = Nilai pasar kekayaan secara riil dalam mata uang domestik

$\pi_{\mathrm{e}}=$ Tingkat perubahan harga mata uang asing yang diharapkan

Untuk menentukan fungsi nilai permintaan kekayaan yang optimal dengan kendala

Rates and The State of World Trade and Payments, Ballinger Publishing Company, hal. 130

2 Ibid, hal. 131 tingkat kekayaan, maka permintaan kekayaan asing dirumuskan sebagai berikut:

$$
\begin{aligned}
\mathrm{F}^{\mathrm{d}} \frac{\mathrm{e}}{\mathrm{P}}= & \mathrm{F}\left(\mathrm{r}, \mathrm{r}^{*}+\pi_{\mathrm{e}}\right) \frac{\mathrm{A}}{\mathrm{P}} \equiv \\
& \left(1-\mathrm{D}\left(\mathrm{r}, \mathrm{r}^{*}+\pi_{\mathrm{e}}\right)\right) \frac{\mathrm{A}}{\mathrm{P}}=\mathrm{F}^{\mathrm{s}} \frac{\mathrm{e}}{\mathrm{P}}
\end{aligned}
$$

dimana:

$\mathrm{F}^{\mathrm{d}}=$ Permintaan kekayaan (assets) asing dalam mata uang asing

$\mathrm{F}^{\mathrm{s}}=$ Penawaran kekayaan (assets) asing

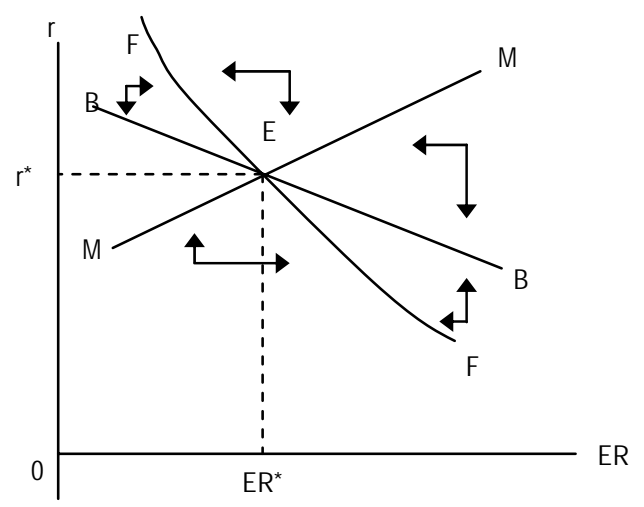

Sumber: (David Bigman and Teizo Taya, 1984 : 136)

\section{Gambar 1. Keseimbangan Pasar Valuta Asing dan Pasar Uang Domestik}

Stabilitas mata uang merupakan persoalan yang penting untuk mendorong kegiatan ekonomi dan menciptakan pertumbuhan ekonomi. Kebijakan stabilisasi nilai tukar mata uang terkait dengan sistem devisa yang diterapkan pada suatu perekonomian. Pemilihan sistem nilai tukar secara garis besar dapat ditinjau dari tiga aspek yaitu karakteristik struktur perekonomian, sumber 
gejolak (source of shock) dan kredibilitas pengambil kebijakan (policy maker). ${ }^{3}$

Model yang digunakan untuk menjelaskan mekanisme penyesuaian yang diperlukan untuk meredam gejolak yang mempengaruhi perekonomian yaitu dengan model persamaan struktural Mundell-Flemming yang dirumuskan Obstfeld (1985) sebagai berikut: ${ }^{4}$

$$
\mathrm{Y}^{\mathrm{d}}=\eta \mathrm{q}_{\mathrm{t}}-\sigma\left(\mathrm{i}_{\mathrm{t}}-\mathrm{E}_{\mathrm{t}}\left(\mathrm{p}_{\mathrm{t}+1}-\mathrm{p}_{\mathrm{t}}\right)\right)+\mathrm{d}_{\mathrm{t}}
$$

Persamaan di atas merupakan persamaan IS pada perekonomian terbuka (open economy) yang menyatakan bahwa output (Y) yang dipengaruhi oleh nilai tukar riil (q), perbedaan suku bunga riil $\left(\mathrm{E}_{\mathrm{t}}\left(\mathrm{p}_{\mathrm{t}+1}-\mathrm{p}_{\mathrm{t}}\right)\right.$ dan variabel eksogen (d). Fungsi permintaan uang dirumuskan sebagai berikut: ${ }^{5}$

$\mathrm{M}_{\mathrm{t}}-\mathrm{p}_{\mathrm{t}}=\mathrm{Y}_{\mathrm{t}}-\lambda \mathrm{i}_{\mathrm{t}}$

dimana permintaan uang riil $\left(\mathrm{M}_{\mathrm{t}}-\mathrm{p}_{\mathrm{t}}\right)$ dipengaruhi oleh tingkat output (Y) dan perbedaan suku bunga nominal (i). Sedangkan fungsi tingkat harga dirumuskan sebagai berikut: ${ }^{6}$

$P_{t}=(1-\theta) E_{t-1} p_{t}+\theta p_{t}$

Harga yang terjadi di pasar barang merupakan rata-rata tertimbang antara harga aktual yang terjadi di pasar dan ekspektasi harga pada periode sebelumnya. Banyak penelitian yang telah dilakukan para ahli

\footnotetext{
${ }^{3}$ Ibid, hal. 153

${ }^{4}$ Ibid, hal, 159

5 Loc-cit

${ }^{6}$ Loc-cit
}

ekonomi mengenai nilai tukar mata uang diantaranya dilakukan oleh Rudiger Dornbusch (1979) mengenai Monetary Policy under Exchange Rate Flexibility. ${ }^{7}$ Dalam penelitian tersebut dijelaskan bahwa ekspektasi nilai tukar merupakan permasalahan utama yang mempengaruhi perubahan pada pasar modal yang dijelaskan melalui pendekatan moneter pada perekonomian terbuka. Juga dijelaskan bahwa neraca transaksi berjalan (current account) merupakan faktor utama yang mendasari perubahan nilai tukar.

Michael D. Mekenzie (2001) yang melakukan penelitian mengenai fluktuasi nilai mata uang dengan metode ARCH (autoregressive conditional heteroscedasticity). Penelitian ini juga digunakan untuk memprediksi fluktuasi mata uang pada masa yang akan datang. ${ }^{8}$ Dalam penelitiannya dirumuskan bahwa peningkatan jumlah uang beredar secara relatif atau penurunan tingkat pendapatan relatif akan menyebabkan terjadinya depresiasi nilai tukar sama halnya jika terjadi kenaikan tingkat bunga domestik.

Penelitian mengenai fluktuasi mata uang juga dilakukan oleh Angelos Kanas dan Georgios P. Kouretas (2001) yaitu untuk mengetahui faktor-faktor yang mendorong terjadinya gejolak perubahan (volatility) nilai tukar mata uang dan kontrol modal baik pada pasar gelap (black market) maupun pasar resmi (official market) dengan mengambil pengalaman negara Yunani. Dalam penelitiannya diketahui bahwa kemampuan dalam memprediksi volatilitas nilai tukar dari

\footnotetext{
7 Ibid, hal. 269

8 Michael D Mckenzie, 2001, "Forecasting Australian Exchange Rate Volatility A Comparative Study of Alternate Modelling Techniques and The Impact of Power Transformations' dalam Journal Departement of Economics and Finance, RMIT
} 
metode GARCH $(1,1)$ memberikan akurasi yang lebih tepat tentang informasi pasar dibandingkan dengan dua metode pengukuran tradisional lain. ${ }^{9}$

\section{METODE PENELITIAN}

Berdasarkan landasan teoritik dan hasil penelitian sebelumnya yang menjadi pijakan dalam melakukan penelitian, maka proses metodologi penelitian berikut yaitu merumuskan paradigma penelitian sebagai gambaran singkat mengenai proses dan alur penelitian yang akan dilakukan sebagai berikut:

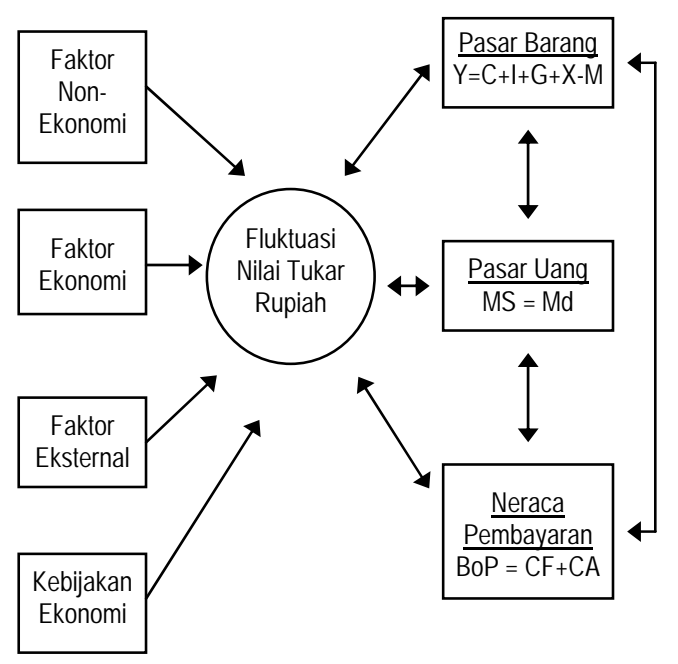

Gambar 2. Proses dan Alur Penelitian

\section{Jenis dan Sumber Data}

Jenis data dalam penelitian ini adalah data sekunder yang merupakan data runtut waktu

\footnotetext{
9 Angelos Kanas and Georgios P Kouretas,2001, "Black and Official Exchange Rate Volatility and Foreign Exchange Controls Evidence from Greece", International Journal of Finance and Economics, vol. $6,13-25$
}

(time series). Adapun data yang dikumpulkan bersumber dari Badan Pusat Statistik (BPS), Asian Development Bank (ADB), International Financial Statistics (IFS), Bank Indonesia, Departemen Keuangan dan sumber informasi data lain yang kredibel dengan kurun waktu dari tahun 1990 triwulan I sampai dengan tahun 2004 triwulan II yang dipakai sebagai bahan analisis statistik kuantitatif sehingga dapat memberikan informasi yang akurat bagi pengambilan keputusan. Data yang digunakan dalam penelitian tentang analisis fluktuasi nilai tukar Rupiah dan implikasinya pada perekonomian Indonesia merupakan data triwulanan antara kurun waktu tahun 1990 tahun 2004 dengan pertimbangan bahwa kurun waktu tersebut mencakup kondisi dan situasi perekonomian Indonesia baik sebelum terjadinya krisis ekonomi maupun setelah terjadinya krisis ekonomi.

\section{Hipotesis Penelitian}

Berdasarkan latar belakang masalah, rumusan masalah, kajian teoritis dan empiris, kerangka pemikiran, asumsi-asumsi serta model penelitian yang telah dikemukakan di atas, maka dapat dirumuskan hipotesis penelitian sebagai berikut:

1. Indeks harga konsumen, neraca pembayaran, jumlah uang beredar berpengaruh positif dan signifikan terhadap fluktuasi nilai tukar Rupiah

2. Aliran modal dan rasio tingkat bunga domestik atas tingkat bunga internasional berpengaruh negatif dan signifikan terhadap fluktuasi nilai tukar Rupiah

3. Krisis ekonomi berpengaruh secara signifikan terhadap nilai tukar Rupiah 


\section{Metode Analisis}

Metode estimasi Error Correction Model (ECM) merupakan model analisis dinamik untuk menjelaskan pengaruh perubahan variabel independen terhadap variabel dependen dalam jangka pendek maupun jangka panjang. Dalam model ECM dengan memasukkan variabel ECT (error correction term). Koefisien regresi variabel ECT merupakan koefisien penyesuaian (coeficient of adjustment) yang juga sekaligus menunjukkan kecepatan penyesuaian (speed of adjustment) antara nilai aktual (actual) dengan nilai diinginkan (desired) yang akan dieliminasi dalam satu periode. Karakteristik model ECM yang valid manakala memenuhi ketentuan bahwa nilai koefisien ECT $(\omega)$ terletak dalam range $0<\omega<1$ dan secara statistik harus signifikan.

\section{Metode Pengujian}

\section{Uji Akar-akar Unit (Unit Roots Test)}

Suatu data atau variabel disebut stasioner jika nilai rata-rata (mean) dan varians konstan selama periode pengamatan. Dengan asumsi stasioneritas maka mampu menterjemahkan data dan model ekonomi secara baik karena data yang stasioner tidak terlalu bervariasi dan cenderung mendekati nilai rata-ratanya. Sebaliknya pada data yang tidak stasioner akan dipengaruhi oleh waktu dan cenderung menyimpang dari nilai rata-ratanya dan selanjutnya dapat menyebabkan terjadinya regresi lancung (spurious regression). Untuk menguji apakah data atau variabel yang dianalisis dalam penelitian ini stasioner ataukah tidak, maka dilakukan uji stasioneritas dengan uji akar-akar unit (unit roots test). Untuk mengetahui apakah hasil dari uji stasioneritas di atas menunjukkan suatu data stasioner atau tidak, maka harus dibandingkan dengan tabel nilai kritis berikut.

Tabel 2. Nilai Kritis untuk t pada Uji ADF N (jumlah sampel) $=33$

\begin{tabular}{cc}
\hline Tingkat Signifikansi & Nilai Kritis \\
\hline 0,01 & $-3,6852$ \\
0,05 & $-2,9705$ \\
0,10 & $-2,6242$ \\
\hline
\end{tabular}

Sumber: Fuller (1976)

\section{Uji Derajat Integrasi}

Selanjutnya setelah dilakukan uji akar-akar unit dapat dilanjutkan dengan melakukan uji derajat integrasi jika uji akar-akar unit ternyata data yang diamati tidak stasioner. Definisi integrasi suatu data adalah bahwa jika data runtut waktu (time series) $\mathrm{X}$ dikatakan berintegrasi pada derajat $\mathrm{d}$ atau ditulis I(d) jika data tersebut perlu didiferensiasi sebanyak d kali untuk dapat menjadi data yang stasioner atau $\mathrm{I}(0)$.

\section{Uji Goodness of Fit (Uji Kecocokan Model)}

Untuk melihat sejauh mana model yang dirumuskan dapat menerangkan variasi perubahan variabel endogen dilakukan dengan uji kecocokan model (uji goodness of fit). Dalam uji ini dilihat nilai koefisien determinasi $\left(\mathrm{R}^{2}\right)$, jika nilai $\mathrm{R}^{2}$ tinggi berarti model yang dirumuskan dapat menerangkan variasi perubahan variabel endogen. Sebaliknya jika nilai $\mathrm{R}^{2}$ kecil berarti bahwa model yang dirumuskan lemah dalam menjelaskan variasi perubahan variabel endogen. 


\section{Uji Signifikansi Garis Regresi secara Keseluruhan (Overall Test)}

Interpretasi terhadap hasil perhitungan adalah dengan ketetapan sebagai berikut jika nilai Fhitung lebih besar dari pada $\mathrm{F}$ tabel pada derajat kesalahan tertentu $(\alpha)$ dengan derajat kebebasan $\mathrm{k}-1$ dan $\mathrm{N}-1$, maka Ho ditolak. Hal ini dapat diartikan bahwa variabel independen secara bersama-sama berpengaruh secara signifikan terhadap variabel endogen. Tetapi sebaliknya jika $\mathrm{F}$ hitung lebih kecil dari pada nilai $\mathrm{F}$ tabel, maka artinya bahwa Ho diterima sehingga variabel independen secara simultan tidak berpengaruh secara signifikan terhadap variabel endogen.

\section{Uji Signifikansi Parameter (Partial test atau Uji-t)}

Uji signifikansi parameter (uji-t) adalah untuk mengetahui pengaruh secara parsial masing-masing variabel independen terhadap variable endogen dalam persamaan reduced form. Jika nilai t-hitung lebih besar dari pada nilai t-kritis, maka Ho ditolak berarti variabel independen berpengaruh secara signifikan terhadap variabel endogen. Hal ini menunjukkan bahwa tanda dan besaran parameter mempunyai arti penting dalam suatu model. Tetapi sebaliknya jika nilai t-hitung lebih kecil dari pada nilai t-kritis berarti bahwa baik tanda maupun besaran estimator tersebut tidak ada nilainya karena sebenarnya nilai parameter tersebut sama dengan nol. Dalam suatu penelitian toleransi kesalahan $(\alpha)$ maksimum adalah 10 persen atau taraf kepercayaan minimum 90 persen dan jika nilainya di bawah ini berarti tidak signifikan.

\section{Uji Asumsi Klasik}

Untuk memperoleh hasil estimasi yang valid dan akurat, maka parameter estimasi harus lolos dari uji asumsi klasik yaitu uji otokorelasi, uji multikolinearitas dan uji heteroskedastisitas.

\section{ANALISIS HASIL PENELITIAN}

Sebelum menganalisis data penelitian mengenai fluktuasi nilai tukar Rupiah dan implikasinya pada perekonomian Indonesia, maka dilakukan pengujian terhadap data-data makroekonomi. Hasil uji akar-akar unit dalam penelitian ini dapat dilihat pada tabel 3.

Tabel 3. Hasil Uji Akar-akar Unit (unit roots test)

\begin{tabular}{ccc}
\hline \multirow{2}{*}{ Variabel } & \multicolumn{2}{c}{ Uji Akar-akar Unit } \\
\cline { 2 - 3 } & DF & ADF \\
\hline C & $-1,574511$ & $-1,569909$ \\
I & $-2,014321$ & $-2,237762$ \\
G & $-1,748518$ & $-1,604175$ \\
X & $-1,896573$ & $-1,823969$ \\
Z & $-1,780904$ & $-1,965982$ \\
GDP & $-1,679315$ & $-1,756409$ \\
GDPDN & 0,199594 & 0,076585 \\
RDNLN & $-2,288979$ & $-2,259081$ \\
ToT & $-3,079226$ & $-2,095970$ \\
ER & $-0,990871$ & -0999791 \\
SHLN & $-1,470297$ & $-1,690734$ \\
rs & $-2,816700$ & $-2,942546$ \\
rk & $-1,896769$ & $-2,636270$ \\
M1 & 2,487195 & 3,263387 \\
CPI & $-2,113440$ & $-1,979590$ \\
CF & $-3,603502$ & $-2,294711$ \\
BoP & $-6,322971$ & $-5,246548$ \\
SBI & $-2,413371$ & $-2,947352$ \\
\hline
\end{tabular}

Sumber: data sekunder (diolah)

Hasil uji derajat integrasi di atas menunjukkan bahwa semua variabel yang tidak stasioner pada data asli setelah dilakukan uji 
akar-akar unit pada first difference telah mencapai keadaan yang stasioner. Variabel CPI, ER, G, GDPDN, I, C, PDB, SHLN, X, dan Z. dari hasil uji derajat integrasi telah mencapai keadaan stasioner dengan uji akarakar unit pada first difference karena nilai test statistiknya signifikan pada critical value $10 \%$.

\section{Metode Estimasi Error Correction Model (ECM)}

Metode estimasi dinamik ECM untuk menganalisis perubahan nilai tukar Rupiah terhadap dollar AS secara dinamis baik dalam jangka pendek maupun jangka panjang, Tabel 4 mengungkapkan hasil penelitian dengan metode ECM.

Agar metode estimasi ECM dikatakan sahih, maka harus memenuhi beberapa kriteria yaitu koefisien regresi dari variabel error correction term (ECT) nilainya $0<\psi<$ 1. Kriteria berikutnya bahwa nilai t-statistik dari koefisien regresi variabel ECT harus signifikan dan bertanda positif. Koefisien regresi variabel ECT merupakan koefisien penyesuaian (coeficient of adjustment) yang menunjukkan besarnya ketidaksesuaian antara nilai aktual (actual) dengan nilai diinginkan (desired) yang akan dieliminasi dalam satu periode. Jika metode estimasi ECM memenuhi kriteria tersebut dikatakan bahwa model ECM dapat dipakai untuk mengestimasi suatu fungsi persamaan dengan baik.

Hasil estimasi dinamis dengan metode ECM di atas menunjukkan bahwa metode estimasi ECM sahih karena telah memenuhi kriteria sebagai model estimasi dimana nilai koefisien regresi ECT sebesar 0,051906 dengan nilai t-statistik sebesar 2,062615 > ttabel pada $\alpha$ (level of significance) $5 \%$ dengan derajat kebebasan (degree of freedom) $\mathrm{n}-\mathrm{k}-1$. Nilai koefisien regresi ECT (error correction term) yang sekaligus juga menunjukkan kecepatan penyesuaian (speed of adjustment) nilai tukar Rupiah menuju ke keseimbangan dengan nilai sebesar 0,051906 artinya bahwa sekitar

Tabel 4. Analisis Estimasi Nilai Tukar Rupiah Metode ECM

\begin{tabular}{lrrrll}
\hline \multicolumn{5}{c}{ Error Correction Model (ECM) } \\
\hline Variabel & Koefisien & t-statistik & Prob. & \multicolumn{2}{c}{ Uji Diagnostik } \\
\hline Konstanta & 575,0900 & 0,814344 & 04200 & AlC & 16,74132 \\
D(RDNLN) & $-100,0143$ & $-0,846706$ & 0,4020 & SC & 17,24766 \\
D(BoP) & $-0,541937$ & $-2,253419$ & 0,0295 & Ramsey Test & 2,895749 \\
D(CF) & 0,480588 & 2,238415 & 0,0306 & J-B & 3,975161 \\
D(CPI) & 0,410951 & 0,072568 & 0,9425 & B-G & 1,090522 \\
D(M1) & 0,040934 & 1,689115 & 0,0986 & White test & 31,46473 \\
D(Dummy) & 945,6358 & 1,234966 & 0,2237 & F-statistik & 1,985897 \\
RDNLN(-1) & 24,72756 & 0,292030 & 0,7717 & R $^{2}$ Adjusted & 0,188990 \\
BoP(-1) & $-0,700165$ & $-2,502589$ & 0,0163 & t-tabel $\alpha=5 \%$ & 1,672 \\
CF(-1) & 0,234516 & 1,352711 & 0,1834 & & \\
CPI(-1) & $-6,269850$ & $-1,245395$ & 0,2199 & & \\
M1(-1) & 0,005039 & 0,978732 & 0,3333 & & \\
Dummy(-1) & 631,0882 & 1,721655 & 0,0925 & & \\
ECT & 0,051906 & 2,062615 & 0,0454 & & \\
\hline
\end{tabular}

Sumber: data sekunder (diolah) 
5,1906\% ketidaksesuaian antara nilai tukar Rupiah aktual (actual) dengan nilai tukar Rupiah yang diinginkan (desired) akan dieliminasi dalam satu periode.

Metode estimasi ECM juga dapat memberikan informasi mengenai bagaimana kaitan perubahan variabel independen terhadap variabel dependen dalam jangka panjang. Untuk menghitung nilai koefisien jangka panjang dari variabel bebas RDNLN, CF, BoP, CPI, MS dan Dummy pada metode estimasi ECM diperoleh hasil perhitungan yang nampak dalam tabel 5 .

Tabel 5. Nilai Koefisien Variabel Independen Jangka Panjang Metode Estimasi ECM

\begin{tabular}{lcc}
\hline \multirow{2}{*}{ Variabel } & \multicolumn{2}{c}{ ECM } \\
\cline { 2 - 3 } & Jangka Pendek & Jangka Panjang \\
\hline Konstanta & 575,0900 & 11079,45 \\
RDNLN & $-100,0143$ & 477,3912 \\
CF & $-0,541937$ & 5,51809 \\
BoP & 0,480588 & $-12,4891$ \\
CPI & 0,410951 & $-119,792$ \\
MS & 0,040934 & 12159,29 \\
Dummy & 945,6358 & 1,097079 \\
ECT & - & - \\
\hline
\end{tabular}

Sumber: data sekunder (diolah)

Metode estimasi ECM menunjukkan bahwa nilai koefisien regresi variabel RDNLN dalam jangka pendek sebesar 100,0143 dengan nilai t-statistik -0,846706 < t-tabel pada $\alpha$ (level of significance) 13\% dengan derajat kebebasan (degree of freedom) $\mathrm{n}-\mathrm{k}-1$. Hasil temuan ini juga membuktikan bahwa dalam jangka pendek rasio tingkat bunga simpanan domestik terhadap tingkat bunga internasional tidak berpengaruh secara signifikan terhadap fluktuasi nilai tukar Rupiah terhadap dollar AS. Temuan empiris ini menyiratkan bahwa variabel tingkat bunga bukan merupakan variabel yang menentukan bagi investor dan pelaku pasar uang dalam menanamkan investasi portfolio. Bagi mereka yang lebih penting adalah sejauhmana komitmen dan konsistensi pemerintah dalam menjalankan kebijakan-kebijakan ekonominya yang dapat memberikan sinyal positif bagi pelaku pasar.

Metode estimasi ECM menunjukkan bahwa dalam jangka pendek besarnya koefisien regresi variabel BoP sebesar 0,541937 dengan nilai t-statistik -2,253419> t-tabel pada $\alpha$ (level of significance) 5\% dengan derajat kebebasan (degree of freedom) $\mathrm{n}-\mathrm{k}-1$ artinya bahwa dalam jangka pendek perubahan variabel BoP berpengaruh secara negatif dan signifikan terhadap fluktuasi variabel ER. Surplus neraca pembayaran (BoP) sebesar 1 juta/\$ AS akan mendorong apresiasi nilai tukar Rupiah sebesar 0,419113 Rupiah/\$ AS. Dalam analisis jangka panjang menunjukkan bahwa koefisien regresi variabel $\mathrm{BoP}$ sebesar $-12,4891$ dengan nilai t-statistik $-2,502589>$ t-tabel pada $\alpha$ (level of significance) $5 \%$ dengan derajat kebebasan (degree of freedom) $\mathrm{n}-\mathrm{k}-1$ artinya bahwa dalam jangka panjang perubahan posisi neraca pembayaran berpengaruh secara signifikan terhadap fluktuasi nilai tukar Rupiah terhadap dollar AS.

Temuan empiris ini mengisyaratkan bahwa fundamental ekonomi berpengaruh terhadap fluktuasi nilai tukar mata uang di samping faktor-faktor non ekonomi. Posisi neraca pembayaran mencerminkan kondisi riil perekonomin Indonesia terhadap negara lain menyangkut arus perdagangan barang dan modal. Ada dinamika pengaruh perubahan posisi neraca pembayaran internasional terhadap fluktuasi nilai tukar Rupiah terhadap dollar AS. 
Metode estimasi ECM menunjukkan bahwa dalam analisis jangka pendek nilai koefisien regresi variabel CPI sebesar 0,410951 dengan nilai t-statistik $0,072568<$ t-tabel pada $\alpha$ (level of significance) $5 \%$ dengan derajat kebebasan (degree of freedom) $\mathrm{n}-\mathrm{k}-1$ artinya bahwa dalam jangka pendek variabel CPI tidak berpengaruh secara signifikan terhadap fluktuasi nilai tukar Rupiah. Demikian juga dalam analisis jangka panjang bahwa nilai koefisien regresi variabel CPI sebesar -119,792 dengan nilai tstatistik $-1,245395<\mathrm{t}$-tabel pada $\alpha$ (level of significance) $5 \%$ dengan derajat kebebasan (degree of freedom) $\mathrm{n}-\mathrm{k}-1$ artinya bahwa dalam jangka panjang variabel CPI juga tidak berpengaruh secara signifikan terhadap fluktuasi nilai tukar Rupiah.

Metode estimasi ECM menunjukkan bahwa dalam jangka pendek nilai koefisien regresi variabel MS sebesar 0,040934 dengan nilai t-statistik $1,689115>$ t-tabel pada $\alpha$ (level of significance) $5 \%$ dengan derajat kebebasan (degree of freedom) $\mathrm{n}-\mathrm{k}-1$ artinya bahwa dalam jangka pendek peningkatan jumlah uang beredar sebesar 1 milyar Rupiah akan menyebabkan depresiasi nilai tukar Rupiah terhadap dollar AS sebesar 0,040934 Rupiah/\$ AS. Dalam jangka panjang nilai koefisien regresi variabel MS sebesar 1,097079 dengan nilai t-statistik 0,978732< t-tabel pada $\alpha$ (level of significance) $5 \%$ dengan derajat kebebasan (degree of freedom) $\mathrm{n}-\mathrm{k}-1$ artinya bahwa dalam jangka panjang perubahan jumlah uang beredar tidak berpengaruh secara signifikan terhadap perubahan nilai tukar Rupiah terhadap dollar AS. Hasil temuan empiris ini menunjukkan bahwa para pelaku ekonomi merespon kebijakan perubahan jumlah uang beredar dalam konteks ekonomi jangka pendek sedangkan dalam jangka panjang relatif tetap dan stabil karena para pelaku ekonomi telah melakukan ekspektasi dan penyesuaian berdasarkan pengalaman sebelumnya.

Metode estimasi ECM membuktikan bahwa dalam jangka pendek keadaan krisis ekonomi tidak berpengaruh terhadap fluktuasi nilai tukar Rupiah terhadap dollar AS. Nilai koefisien regresi variabel krisis ekonomi sebesar 945,6358 dengan nilai tstatistik 1,234966< t-tabel pada $\alpha$ (level of significance) $5 \%$ dengan derajat kebebasan (degree of freedom) $\mathrm{n}-\mathrm{k}-1$ artinya bahwa dalam jangka pendek kondisi krisis ekonomi tidak berpengaruh secara signifikan terhadap fluktuasi nilai tukar Rupiah terhadap dollar AS. Dalam jangka panjang diperoleh temuan bahwa nilai koefisien regresi variabel krisis ekonomi sebesar 12159,29 dengan nilai tstatistik 1,721655 > t-tabel pada $\alpha$ (level of significance) $5 \%$ dengan derajat kebebasan (degree of freedom) $\mathrm{n}-\mathrm{k}-1$ artinya bahwa dalam jangka panjang krisis ekonomi berpengaruh secara positif dan signifikan terhadap fluktuasi nilai tukar Rupiah terhadap dollar AS.

Krisis ekonomi menimbulkan kepanikan di tengah masyarakat sehingga menimbulkan ketidakpastian yang berakibat masyarakat mengambil langkah mengamankan nilai kekayaan dari kemungkinan merosot di kemudian hari dengan menukar Rupiah dengan dollar AS. Kejadian ini terasa benar pada saat Indonesia mengalami krisis moneter menjelang turunnya rezim orde baru tahun 1997 dimana Rupiah sempat hampir menyentuh angka Rp. 20.000/\$ AS. Namun seiring dengan langkah-langkah kebijakan konsolidasi ekonomi dan kondisi politik yang semakin stabil, maka nilai Rupiah berangsurangsur pulih kembali. 


\section{KESIMPULAN}

1. Pengaruh dinamika jangka pendek dan jangka panjang menunjukkan bahwa perubahan rasio tingkat bunga simpanan domestik terhadap tingkat bunga internasional tidak berpengaruh secara signifikan terhadap perubahan nilai tukar Rupiah terhadap dollar AS. Temuan empiris ini terkait dengan pola kebijakan moneter yang bersifat reaktif bukan proaktif sehingga pemerintah terkesan kurang responsif terhadap perkembangan pasar uang internasional.

2. Sedangkan dalam analisis dinamis jangka pendek perubahan aliran modal berpengaruh positif dan signifikan terhadap nilai tukar Rupiah sebesar 0,480588. Temuan empiris ini terkesan kontradiktif dengan temuan analisis keseimbangan makro ekonomi namun hal ini bisa dipahami mengingat dinamika yang sangat tinggi menyangkut aliran modal menyangkut sensitivitas pelaku pasar terhadap setiap perubahan baik menyangkut kebijakan ekonomi pemerintah atau faktor-faktor non ekonomi lainnya.

3. Sedangkan dalam analisis ekonomi dinamis jangka pendek dan jangka panjang diketahui bahwa neraca pembayaran berpengaruh secara signifikan terhadap nilai tukar Rupiah sebesar $-0,541937$ dan $-12,4891$. Temuan empiris dengan pendekatan dinamik ini juga sifatnya kontradiktif dengan pendekatan keseimbangan makro ekonomi. Namun hal ini juga bisa dipahami bahwa dalam analisis dinamis perubahan kebijakan ekonomi dan faktor-faktor non ekonomi sangat sensitif terhadap perubahan nilai tukar Rupiah.
4. Indeks harga konsumen dalam analisis dinamis jangka pendek dan jangka panjang tidak berpengaruh secara signifikan terhadap nilai tukar Rupiah terhadap dollar AS. Hal ini menyiratkan keberhasilan kebijakan pemerintah dalam mengendalikan laju inflasi pada tingkat yang wajar yaitu di bawah dua digit untuk menjaga stabilitas ekonomi nasional.

5. Dalam analisis ekonomi dinamis jangka pendek jumlah uang beredar berpengaruh secara positif dan signifikan terhadap nilai tukar Rupiah sebesar 0,040934 artinya bahwa peningkatan jumlah uang beredar sebesar 1 milyar Rupiah akan mendorong depresiasi nilai tukar Rupiah sebesar 0,040934 Rupiah/\$ AS. Sedangkan dalam analisis jangka panjang jumlah uang beredar tidak berpengaruh secara signifikan terhadap nilai tukar Rupiah. Dari temuan empiris ini menyiratkan bahwa jumlah uang beredar merupakan variabel makroekonomi yang berpengaruh terhadap nilai tukar Rupiah terhadap dollar AS. Karena dengan semakin meningkatnya jumlah uang beredar akan berdampak pada peningkatan inflasi sehingga akan menurunkan nilai Rupiah terhadap dollar AS.

6. Dalam jangka panjang keadaan krisis ekonomi berpengaruh secara positif dan signifikan terhadap nilai tukar Rupiah terhadap dollar AS. Krisis ekonomi menimbulkan depresiasi nilai Rupiah sebesar 12159,29 Rupiah/\$ AS. Fenomena ini menjelaskan bahwa krisis ekonomi menimbulkan kepanikan pasar dan para pelaku pasar berusaha melindungi kekayaan dari kemungkinan rugi di kemudian hari dengan menukar Rupiah dengan 
dollar sehingga Rupiah terus terkoreksi. Nilai Rupiah kembali menguat seiring dengan semakin pulihnya kondisi ekonomi dan politik serta keyakinan masyarakat akan kemampuan pemerintah dalam mengendalikan stabilitas ekonomi dan politik nasional.

\section{DAFTAR PUSTAKA}

Adams, John, 1999, The Contemporary International Economy Reader, second edition, New York: St. Martin Press.

Aghevli, BB, 1976, "A Model of the Monetary Sector for Indonesia 1968-1973", Bulletin of Indonesian Economic Studies, vol. 12/3, p. 50-60.

Aghevli, BB, 1977, "Money, Price and the Balance of Payment: Indonesia, 19681973”, Journal of Development Studies, vol. $13 / 2$, p. $35-57$.

Aghevli, BB, 1999, “An Econometric Model of Monetary Sector for Indonesia", Journal of Development Studies.

Aghevli, BB and Khan MS, 1978, "Government Deficits and the Inflationary Process in Developing Countries", IMF Staff Papers

Aghevli, BB, 1978, “Government Deficits and the Inflationary Process in Developing Countries", IMF Staff Papers.

Angelos Kanas and Georgios P Kouretas, 2001, "Black and Official Exchange Rate Volatility and Foreign Exchange Controls Evidence from Greece", International Journal of Finance and Economics 6.

Arsyad Anwar, 1985, Prospek dan Permasalahan Ekonomi Indonesia 1985-1986, edisi pertama Jakarta: Fakultas Ekono- mi Universitas Indonesia dan Sinar Harapan.

Baffes, John, Ibrahim A Elbadawi, Stephen A O'Connell, 1997, Single Equation Estimation of the Equilibrium Real Exchange Rate, Journal of Economics.

Betts, Caroline and Michael B Devereux, 2000, Exchange Rate Dynamics in a Model of Pricing to Market, Journal of International Economics 50, 215-244

Bigman David and Teizo Taya, 1984, Floating Exchange Rates and the State of World Trade and Payments, Ballinger Publishing Company.

Bodnar, GB and R Marston, 2000, "A Simple Model of Foreign Exchange Exposure”, mimeo, October 30,

Bodnar, G, F Wong, 2000, "Estimating Exchange Rate Exposure Some Weighty Issues, NBER Working Paper 7497, January.

Boediono, 1979, Econometric Models of the Indonesian Economy for Short Run Policy Analysis, Dissertation PhD, University of Pennsylvania.

Bordo, Michael D and Harold James, 2001, "The Adam Klug Memorial Lecture Haberler versus Nurkse the Case for Floating Exchange Rates as an Alternative to Breton Woods, NBER Working Paper, October.

Bordo, Michael, 2001, "Core Periphery Exchange Rate Regimes and Globalization," NBER Working Paper, November.

Branson, William H, 2000, Macroeconomic Theory and Policy, third edition, New York: Harper and Row Publisher. 
Chacholiades, Miltiades, 1973, The Pure Theory of International Trade, London: The MacMillan Press.

Chiang, Alpha C, 2002 Fundamental Methods of Mathematical Economics, third edition, International Student Edition, New York: McGraw-Hill Inc.

Cooney John W, Bonnie van Ness and Robert van Ness, 2000, "Do Investors Avoid Odd-Eighths Prices? Evidence from NYSE Limit Orders", Mimeo (December).

Dernburg, Thomas F, 2001, Makroekonomi, terjemahan Muhtar, edisi ketujuh, Jakarta: Penerbit Erlangga.

Dominguez K and L Tesar, 2001a "A ReExamination of Exchange Rate Exposure", American Economic Review Papers and Proceedings, May

Dominguez K and L Tesar, 2001, "Exchange Rate Exposure," NBER Working Paper 8453, September.

Dornbusch, Rudiger dan Fischer Stanley, 2002, Makroekonomi, edisi ketiga, terjemahan Sitompul, Jakarta: Erlangga.

Dornbusch, Rudiger, 1980, Open Economy Macroeconomics, New York: Basic Books Inc.

Evans, Martin, 2001, "FX Trading and Exchange Rate Dynamics," NBER Working Paper 8116 (February)

Gallagher, T Kenneth, 1994, Epistemology Filsafat Pengetahuan, Yogyakarta: Penerbit Kanisius.

George, J Hall, 2001, "Exchange Rates and Casualties during the First World War," Cowles Foundation Discussion Paper No. 1321, August.
Glassburner, Bruce dan Chandra Aditiawan, 1982, Teori dan Kebijaksanaan Ekonomi Makro, edisi kedua, Jakarta: LP3ES.

Goldberg Michael, 2000, "Do Monetary Models of The Exchange Rate with RE Fit The Data?" Mimeo, University of New Hampshire (November).

Granger, CWJ and Newbold, Paul, 2002, Forecasting Economic Time Series, Academic Press, New York San Francisco London, p.333

Griffin John and Rene Stulz, 2001, "International Competition and Exchange Rate Shocks A Cross Country Industry Analysis of Stock Returns," Review of Financial Studies, spring, 215-241.

Groosman, Gene M, 1992: Imperfect Competition and International Trade, NJ: The MIT Press.

Grauwe Paul de and Isabel Vansteenkiste, 2001, "Exchange Rates and Fundamentals a Non Linear Relationship?" $C E$ Sifo Working Paper No. 577, October.

Grubel, Herbert G, 1981, International Economics, Richard D Irwin Inc.

Gujarati, Damodar N, 2002, Basic Econometrics, Fifth edition, London: McGraw -Hill.

Harun Hadiwijoyo, 1980, Sari Sejarah Filsafat Barat, Jilid I dan II, Yogyakarta: Penerbit Kanisius.

Hausmann Ricardo, Ugo Panizza and Ernesto Stein, 2000, "Why do Countries Float the Way They Float? JADB Working Paper, No. 418.

Hongwei Du and Zhen Zhu, 2001, "The Effect of Exchange Rate Risk on Exports Some Additional Empirical Evi- 
dence," Journal of Economic Studies, Vol 28 No. 2, pp. 106-121.

Harris, Laurence, 1985, Monetary Theory, second edition, New York: McGrawHill Book Company.

Havrilesky T and Boorman J, 1976, Current Issues in Monetary Theory and Policy, AHM Publishing Corporation.

Henderson, James M, Quandt Richard E, 1980, Microeconomic Theory a Mathematical Approach, third edition, International Student Edition, New York: McGraw-Hill International Book Company.

Herman Soewardi, 2000, Roda Berputar Dunia Bergulir Kognisi Baru tentang Timbul-tenggelamnya Sivilisasi, edisi I, Bandung: Bakti Mandiri.

Hill, Hall, 1996, The Indonesian Economic since 1966 Southeast Asia's Emerging Giant, London: Cambridge University Press.

IMF, 1998, World Economic Outlook, May, Washington DC, International Monetary Fund.

Imamudin Yuliadi, 2001, Analisis Makroekonomi Indonesia Pendekatan IS-LM, tesis, Yogyakarta: Universitas Gadjah Mada.

Insukindro, 1990, "Komponen Koefisien Regresi Jangka Panjang Model Ekonomi Studi Kasus Impor Barang di Indonesia”, Journal Ekonomi dan Bisnis Indonesia, No. 2 tahun $V$

Insukindro, 1992, "Pembentukan Model dalam Penelitian Ekonomi”, Jurnal Ekonomi dan Bisnis Indonesia, tahun VII, No. 1
Insukindro, 1996, "Pendekatan Masa Depan dalam Penyusunan Model Ekonometrika: Forward-looking Model dan Pendekatan Kointegrasi', Jurnal Ekonomi dan Industri, tahun kedua, edisi kedua

Insukindro, 1998, "Pendekatan Stok Penyangga Permintaan Uang: Tinjauan Teoritik dan Sebuah Studi Empirik di Indonesia", Ekonomi dan Keuangan Indonesia, Vol. XLVI, No. 4

Insukindro, 1998, Pemilihan Model Ekonomi Empirik dengan Pendekatan Koreksi Kesalahan", Jurnal Ekonomi dan Bisnis Indonesia, Vol. 14, No. 1.

Intriligator, Michael D, 1996, Econometric Models, Techniques and Application, New Jersey USA: Prentice-Hall Inc., Englewood Cliffs.

Jeremy Berkowitz and Lorenzo Giorgianni, 1996, "Long Horizon Exchange Rate Predictability?" International Monetary Funds, September 19.

John Geanakoplos and Dimitrios Tsomocos, 2001, "International Finance in General Equilibrium", Cowles Foundation Discussion Paper No. 1313, July.

Kenen, Peter B, 1989, The International Economy, second edition, New Jersey: Prentice Hall, Englewood Cliff.

Kilian L and M Taylor, 2001, "Why is It So Difficult to Beat the Random Walk Forecast of Exchange Rates? University of Mimeo, pp. 29.

Kmenta, Jan, 2000, Elements of Econometric, second edition, London: McGrawHill.

Koutsoyiannis, A, 2002, Theory of Econometric, second edition, New Jersey: Prentice-Hall, Englewood Cliffs. 
Krugman Paul and M Obstfeld, 1988: International Economics Theory and Policy, London: Foresman and Company.

Lilien, David M, 1976, Micro TSP Student Version Used's Manual Version 5.1, Quantitative Micro Software, Irvin California.

Lyons, Richard K, 2001. the Microstructure Approach to Exchange Rates, Book in Draft.

Maddala, GS, 2001, Introduction to Econometrics, second edition, New York: Maxwell MacMillan International Publishing Company.

Malinvaud, E, 1999, Statistical Methods of Econometrics, third revised edition, North Holland Publishing Company, 737.

Mankiw, G N, 2000, Macroeconomics, New York: Worth Publisher Co.

Masson, Paul, 2001, "Exchange Rate Regime Transitions," Journal of Development Economics, January.

McCallum, Bennett T, 1989, Monetary Economics Theory and Policy, New York MacMillan Publishing Company.

Meade, JE, 1956, The Balance of Payment, fourth edition, New York: Oxford University Press.

Michael, D McKenzie, 2003, "Forecasting Australian Exchange Rate Volatility A Comparative Study of Alternate Modeling Techniques and the Impact of Power Transformations," Department of Economics and Finance, RMIT.

Mishkin, S. Frederic, 2001, The Economics of Money Banking and Financial Markets, Addison Wesley.
Mundel, RA, 1968, International Economics, New York: McGraw-Hill.

M. Nasir, 1999, Metode Penelitian, Jakarta: Ghalia Indonesia.

Nopirin, 1983, A Synthesis of Monetary and Keynesian Approach to The Balance of Payments The Indonesian Case 19701979, PhD dissertation, Washington State University, 1983, Unpublished

Nucci F and AF Pozzolo, 2001, "Investment and the Exchange Rate an Analysis with Firm Level Panel Data," European Economic Review 45, pp 259-83.

Obstfeld, M and K Rogoff, 2000, "The Six Major Puzzles in International Macroeconomics Is There a Common Cause? NBER Working Paper 7777, pp.66.

Osler, CL, 2001, "Information, Order Flow, and High Frequency Exchange Rate Dynamics," Mimeo, Federal Reserve Bank of New York.

Osler, CL, 2000, "Support for Resistance Technical Analysis and Intraday Exchange Rates," Federal Reserve Bank of New York Economic Policy Review (July).

Osler, CL, 2001, "Currency Orders and Exchange Rate Dynamics Explaining The Success of Technical Analysis, Federal Reserve Bank of New York, March.

Peursen van CA, 1993, Susunan Ilmu Pengetahuan Sebuah Pengantar Filsafat Ilmu, Jakarta: PT Gramedia.

Pindyck, Robert S and Rubinfeld, Daniel L, 1991, Econometric Model and Economic Forecast, International edition, McGraw-Hill Inc., third edition

Ravn, Morten O., 2000, Consumption Dynamics and Real Exchange Rate, 
Working Paper, London Business School.

Reinhart Carmen M., and Vincent R., Reinhardt, 2000, "What Hurts Most? G3 Exchange Rate or Interest Rate Volatility, NBER Working Paper, July 7.

Rime, Dagfinn, 2000, "Private or Public Information in Foreign Exchange Markets? An Empirical Analysis," Mimeo, April.

Robert, E Lipsey, 1999, "The Role of Foreign Direct Investment in International Capital Flows," NBER Working Paper 7094, April.

Romer, David, 2000, Advanced Macroeconomics, Singapore: McGraw Hill International Editions.

Rossi, Barbara, 2000, "Testing Out-of-Sample Predictive Ability with High Persistence an Application to Models of Nominal Exchange Rate Determination", Princeton University Mimeo (April).

Sadoulet Elisabeth and Alain de Janvry, 1995, Quantitative Development Policy Analysis, Baltimore: The John Hopkins University Press.

Salvatore, Dominick, 1993, International Economics, fourth edition, New York: MacMillan Publishing Company.

Scarth, William M., 1988, Macroeconomics An Introduction to Advanced Methods, Harcourt Brace.

Snowdon Brian, Howard Vane, Peter Wyanrczyk, 1994, A Modern Guide to
Macroeconomics An Introduction to Competing Schools of Thought, Edward Elgar Publishing, Limited

Sritua Arif, 1990, Dari Prestasi Pembangunan sampai Ekonomi Politik, Kumpulan Karangan, Jakarta: Penerbit Universitas Indonesia.

Tawang Alun, 1992, Analisa Ekonomi Utang Luar Negeri, Jakarta: LP3ES.

Thomas, R Leighton, 1985, Introductory Econometrics Theory and Application, first edition, Singapore: British Library Catalog in Publishing Data.

Turnovsky, Stephen J, 1981, Macroeconomic Analysis and Stabilization Policy, USA: Cambridge University Press.

Tulus Tambunan, 2001, Perdagangan Internasional dan Neraca Pembayaran, Jakarta: LP3ES.

West and Cho, 1995, "The Predictive Ability of Several Models of Exchange Rate Volatility", Journal of Econometrics, 69, pp. 367-391.

Wihana Kirana Jaya, 1990, "Seleksi Model Permintaan Uang di Indonesia 19731983, Journal Ekonomi dan Bisnis Indonesia, No. 2 tahun $V$

Zhaoyong Zhang, 1999, “China's Exchange Rate Reform and Its Impact on the Balance of Trade and Domestic Inflation”, Asia Pacific Journal of Economics and Business, Vol. 3 No. 2, December. 